\title{
MODEL HUBUNGAN CITRA MEREK, PERPSEPSI KUALITAS, HARGA DAN INTENSI PEMBELIAN KONSUMEN
}

\author{
Hendryadi $^{1}$ dan Diana Purnamasari ${ }^{2}$ \\ ${ }^{1}$ Fakultas Ekonomi, Universitas Bhayangkara Jakarta Raya \\ Jl. Raya Perjuangan, Marga Mulya, Bekasi Utara, Bekasi, Jawa Barat, Indonesia \\ ${ }^{2}$ Program Studi Manajemen, Fakultas Ekonomi Universitas Islam Attahiriyah \\ Jl. Kampung Melayu Kecil III, No 16, Jakarta Selatan, Jakarta, Indonesia \\ 1hendry.basrah@gmail.com \\ 2diana.sanusi17@gmail.com
}

\begin{abstract}
Penelitian ini menguji hubungan antara citra merek, persepsi kualitas, dan harga pada intensi pembelitian produk pafum merek X. Secara khusus, peran kualitas dan harga ditempatkan sebagai mediator pada hubungan citra merek dengan intensi pembelian. Data dikumpulkan melalui penyebaran kuesioner dengan metode convenience sampling. Sebanyak 117 pelanggan dari tiga supermarket di Jakarta dijadikan responden. Analisis data menggunakan PLS-SEM untuk menguji hipotesis yang diajukan. Hasil empiris menunjukkan bahwa citra merek secara signifikan dan positif berpengaruh terhadap persepsi kualitas dan harga. Citra merek, kualitas, dan harga adalah tiga faktor yang secara langsung mempengaruhi intensi pembelian. Pengujian model mediasi menunjukkan bahwa harga terbukti sebagai mediator hubungan citra merek dengan intensi pembelian, sedangkan persepsi kualitas tidak signifikan. Penelitian ini terbatas pada perilaku pembelian produk parfum sehingga riset mendatang dapat memperluas analisis pada produk yang berbeda.
\end{abstract}

Keywords: brand image, perceived quality, price, purchase intention

\section{PENDAHULUAN}

Era yang sangat kompetitif seperti sekarang ini telah mendorong perhatian dan upaya dari pemasar untuk mempertahankan dan meningkatkan pelanggan yang setia. Hal ini disebabkan karena pelanggan yang memiliki kesetiaan pada sebuah merek akan memberikan kesulitan kepada pesaing untuk memasuki pasar, sehingga aktivitas pemasaran lebih banyak diarahkan pada penciptaan merk yang kuat.

Citra merek atau brand image merupakan persepsi tentang merek yang ditunjukkan oleh asosiasi merek di dalam memori dan pikiran konsumen. Keller (2012) menyebutkan bahwa citra merek bisa dilihat sebagai semua kesadaran, kepercayaan, pendapat, dan perilaku pelanggan yang terkait dengan mereka, baik yang diciptakan secara sengaja atau tidak oleh perusahaan. Konsep citra merek dapat mencakup pengetahuan dan kepercayaan konsumen tentang berbagai merek produk dan atribut non-produknya. Yoo dan Donthu (2001) menyebutkan bahwa citra merek dapat berdampak pada keuntungan masa depan 
perusahaan, arus kas jangka panjang, kesediaan konsumen untuk membayar harga premium, pengambilan keputusan merger dan akuisisi, harga saham, keunggulan kompetitif yang berkelanjutan, dan keberhasilan pemasaran. Penguatan brand image juga dianggap sebagai salah satu alat untuk mencapai keunggulan kompetitif (Whan Park, et al., 2010).

Pentingnya citra merek dalam mempengaruhi perilaku pelanggan maupun keuntungan jangka panjang perusahaan telah menarik perhatian praktisi dan akademisi di bidang ini. Meskipun demikian, masih terdapat perbedaan perspektif yang menyebabkan kesimpulan yang dihasilkan oleh berbagai penelitian masih berbeda satu sama lain. Misalnya, beberapa penelitian menempatkan citra merek sebagai anteseden persepsi kualitas (Chiang dan Jang, 2007; Swait dan Erdem, 2007; Khan et al., 2014), sedangkan yang lain menempatkan citra merek sebagai dampak dari persepsi kualitas (Aydin \& Özer, 2005; Wu et al., 2011; Ranjbarian et al., 2012; Saleem \& Raja, 2014).

Perspektif pertama yang menempatkan citra merek sebagai anteseden persepsi kualitas produk didasarkan pada asumsi bahwa citra merek berasal dari semua pengalaman konsumsi konsumen, dan kualitas yang dirasakan merupakan fungsi dari pengalaman konsumsi ini. Dengan demikian, persepsi pelanggan mengenai kualitas layanan/produk secara langsung mempengaruhi citra merek (Aydin dan Ozer, 2005). Sedangkan perspektif kedua yang menempatkan citra merek sebagai anteseden dari kualitas yang dirasakan didasarkan pada pasar dimana konsumen tidak secara langsung mengetahui kualitas atau belum membeli. Dengan demikian, brand image dibentuk dari komunikasi yang dilakukan oleh pemasar melalui berbagai media promosi, atau memberikan sinyal tidak langsung mengenai kualitas dan harga melalui bauran pemasaran seperti nama merek. Dengan kata lain, merek yang kuat dapat mengenakan harga premium untuk memperkuat hubungan positif antara harga dan kualitas yang dirasakan (Swait dan Erdem, 2007).

Penelitian ini bertujuan untuk menguji model yang menempatkan citra merek sebagai anteseden dari persepsi kualitas dan harga produk, yang akhirnya mempengaruhi intensi pembelian konsumen pada produk parfum merek X. Riset ini berbeda dengan penelitian sebelumnya yang lebih banyak meneliti efek langsung brand image terhadap perilaku pembelian konsumen (Chihab, \& Abderrezzak, 2016; Lien et al., 2015; Calvo \& Porral, 2015), efek tidak langsung brand image terhadap minat beli melalui persepsi kualitas (Kahn et al., 2014) tanpa memasukkan variabel harga, dan pengaruh kualitas dan harga terhadap minat beli (Konuk, 2015; Beneke et al., 2013), atau penelitian Wang dan Yang (2010) yang menguji dampak kredibilitas merek pada niat membeli dan mengusulkan brand awareness dan brand image memainkan peran moderat pada hubungan tersebut.

Penelitian ini diharapkan dapat memberikan pemahaman yang lebih lengkap kepada peneliti dan praktisi mengenai tentang implikasi citra merek terhadap persepsi kualitas, harga dan intensi pembelian. Selain itu, penjelasan mengenai peran mediasi persepsi kualitas dan harga pada hubungan citra merek dan intensi pembelian dapat dijadikan dasar teoritis awal bagi peneliti di bidang manajemen pemasaran.

\section{KERANGKA KONSEPTUAL DAN HIPOTESIS \\ 2.1. Citra Merek (Brand Image)}


Selama satu dekade terakhir, perusahaan telah berupaya meningkatkan investasi mereka dalam penciptaan dan pengembangan merek. Penciptaan merek menyiratkan komunikasi ke semua kelompok sasaran perusahaan seperangkat asosiasi. Aaker (1991: 15) mengkonseptualisasikan ekuitas merek sebagai "satu set aset dan kewajiban merek yang terkait dengan merek, nama dan simbol yang menambah atau mengurangi dari nilai yang diberikan oleh suatu produk atau pelayanan kepada perusahaan dan / atau kepada pelanggan perusahaan itu". Model ini dikembangkan oleh Aaker (1996) mengidentifikasi lima dimensi utama pada ekuitas merek. Kelima indikator tersebut adalah kesadaran merek (brand awareness), asosiasi merek (brand associations), mutu yang dirasakan (perceived quality), loyalitas merek (brand loyalty) dan aset-aset lain yang berkaitan dengan merek (other brand-related assets).

Melanjutkan karya Aaker, Keller (1993) mengembangkan konsep perilaku ekuitas merek berbasis pelanggan / customer based brand equity (CBBE), yang terdiri dari dua dimensi brand awareness dan brand image dan didefinisikan sebagai efek diferensial dari pengetahuan merek terhadap respon pelanggan terhadap pemasaran merek. Citra merek terdiri dari atribut dan manfaat yang terkait dengan merek yang membuat merek berbeda, sehingga dapat membedakan mereka dengan pesaingnya. Atribut adalah fitur deskriptif yang menjadi ciri sebuah merek, seperti yang dipikirkan konsumen tentang merek itu dan apa yang terkait dengan pembelian atau konsumsinya. Bene fi ts adalah nilai konsumen pribadi yang melekat pada atribut merek, yaitu, apa yang konsumen pikir merek dapat lakukan untuk mereka (Keller, 1993, 1998). Dalam hubungan pelanggan-pelanggan, setiap interaksi antara perusahaan dan pelanggannya menjadi masukan terhadap citra merek. Karena merek layanan mengkomunikasikan komitmen untuk memberikan pengalaman tertentu, sangat penting bahwa perusahaan jasa memastikan bahwa setiap orang di dalam organisasi memahami pentingnya memberikan kinerja berkualitas tinggi yang konsisten, dapat diprediksi dan berkualitas kepada pelanggan (Webster dan Keller, 2004).

Istilah citra merek pertama kali diperkenalkan secara formal oleh Gardner dan Levy dan kemudian menjadi perhatian para peneliti di bidang pemasaran. Meski merupakan konsep yang sudah diperkenalkan di era tahun 60-an, konsep brand image dalam perkembangannya telah didefinisikan secara berbeda karena adanya berbedaan focus penelitian. Para peneliti umumnya menyamakan istlilah brand image dan konsep merek lainnya, seperti identitas merek (Bian dan Moutinho, 2011).

Aaker (1996) secara tegas menyatakan bahwa brand image dan brand identity adalah dua konsep yang berbeda, Identitas merek mengacu pada asosiasi merek unik yang oleh para ahli strategi merek ingin diciptakan atau dipertahankan" (Aaker, 1996: 68), dengan demikian, identitas merek menyiratkan sebuah janji. Sedangkan brand image adalah "bagaimana sebuah merek dirasakan oleh konsumen" (Aaker, 1996: 71). Keller (2012) menyebutkan bahwa citra merek bisa dilihat sebagai semua kesadaran, kepercayaan, pendapat, dan perilaku pelanggan yang terkait dengan merek, baik yang diciptakan secara sengaja atau tidak oleh perusahaan. Konsep citra merek dapat mencakup pengetahuan dan kepercayaan konsumen tentang berbagai merek produk dan atribut non-produknya. Penelitian ini selanjutnya mengadopsi definisi citra merek Aaker (1996) dan Keller (2012).

Citra merek memiliki peran penting dan berdampak konsumen dan perusahaan secara langsung. Citra merek yang dikomunikasikan dengan baik dapat membantu membangun posisi merek, melindungi merek dari persaingan, meningkatkan kinerja merek di pasar, dan karena itu memainkan peran integral dalam membangun ekuitas 
merek jangka panjang (Aaker dan Keller, 1990; Keller, 1993; Bian dan Moutinho, 2011). Berikut ini diuraikan kerangka konseptual dan konstruksi hipotesis terkait model yang diusulkan :

\subsection{Hubungan citra merek dengan persepsi kualitas dan harga}

Kotler dan Armstrong (2008) mendefinisikan produk sebagai segala sesuatu yang dapat ditawarkan kepada pasar agar menarik perhatian, diakuisisi, digunakan, atau dikonsumsi yang dapat memuaskan suatu kegiatan atau kebutuhan. Kualitas yang dirasakan adalah penilaian konsumen terhadap nilai tambah suatu produk. Konsumen mengevaluasi kualitas produk berdasarkan pengalaman dan perasaannya sebelumnya (Zeithaml, 1988). Beberapa karakteristik kualitas ini bersifat bawaan, sementara yang lain dapat dilihat pada atribut produk. Karena beberapa karakteristik kualitasnya sulit dideteksi secara langsung, isyarat lain seperti brand image dan brand name menjadi penting dalam mengevaluasi kualitas.

Penelitian sebelumnya telah membuktikan bahwa brand image mempengaruhi persepsi kualitas yang pada gilirannya akan mempengaruhi intensi pembelian. Penelitian Chiang dan Jang (2007) menguji dampak dari persepsi harga dan citra merek terhadap persepsi kualitas, kepercayaan, nilai yang dirasakan, dan niat pembelian. Hasil penelitiannya menyimpulkan bahwa citra merek secara signifikan mempengaruhi kualitas dan kepercayaan yang dirasakan oleh konsumen. Mendukung temuan tersebut, Khan et al., (2014) juga menyimpulkan bahwa citra merek memiliki efek positif pada persepsi kualitas dan kemudian berdampak pada intensi pembelian. Riset Khan secara spesifik menempatkan persepsi kualitas sebagai mediator hubungan citra merek dengan intensi pembelian konsumen. Semakin baik citra merek, semakin positif sikap terhadap produk dan atributnya (Aghekyan-Simonian et al., 2012). Dengan demikian, semakin kuat citra merek yang dirasakan konsumen, maka akan semakin kuat pula persepsi mereka terhadap kualitas produk.

\section{H1 : Citra merek berpengaruh positif terhadap persepsi kualitas produk}

Harga dari sudut pandang konsumen, harga mewakili jumlah uang yang harus diserahkan konsumen untuk mendapatkan produk / jasa (Zeithaml, 1988). Banyak konsumen menggunakan harga sebagai isyarat kualitas yang mencerminkan istilah konvensional bahwa "pembeli mendapatkan apa yang mereka bayar" (Erickson \& Johansson, 1985). Konsumen tidak selalu mengingat harga aktual produk. Sebaliknya, mereka mengkodekan harga dengan cara yang berarti bagi mereka (Zeithaml, 1988). Kotler dan Amstrong (2008) menyebutkan harga adalah sejumlah uang yang ditagihkan atas suatu produk atau jasa, atau jumlah dari nilai yang ditukarkan para pelanggan untuk memperoleh manfaat dan memiliki atau menggunakan produk atau jasa. Dalam keputusan pembelian, konsumen akan cenderung membandingkan harga obyektif (harga yang ditawarkan oleh vendor saat ini) dengan harga referensi (harga yang ditawarkan oleh vendor lain) dan kemudian membentuk persepsi harga mereka (Kim et al., 2012).

\section{$\mathrm{H} 2$ : Harga berpengaruh positif terhadap persepsi kualitas}

Pengaruh citra merek terhadap harga telah berhasil dibuktikan oleh riset sebelumnya. Misalnya Chiang dan Jang (2007) yang menyimpulkan bahwa harga yang ditawarkan lebih rendah dari harga standar atau harga bersaing mereka, menyebabkan persepsi kualitas yang mungkin rendah, namun cenderung memiliki nilai konsumen yang 
tinggi dan lebih cenderung memiliki niat beli yang lebih besar. Lien et al., (2015) memberikan kesimpulan bahwa citra merek secara positif mempengaruhi harga. Dengan demikian, citra merek yang kuat akan memiliki implikasi positif pada persepsi harga konsumen.

\section{H3 : Citra merek berpengaruh positif terhadap persepsi harga}

\subsection{Hubungan citra merek, kualitas, harga, dan intensi pembelian}

Intensi atau niat pembelian adalah kemungkinan bahwa pelanggan akan membeli produk / layanan tertentu (Dodds, Monroe, \& Grewal, 1991). Niat pembelian merupakan prediktor penting dari perilaku pembelian aktual dan hubungan ini telah diuji secara empiris dalam konteks produk maupun jasa. Efek langsung brand image terhadap perilaku pembelian konsumen telah banyak dibuktikan oleh riset sebelumnya. (Chihab, \& Abderrezzak, 2016; Lien et al., 2015; Calvo \& Porral, 2015). Chihab, \& Abderrezzak (2016) meneliti efek citra, harga, perilaku masa lalu terhadap niat pembelian parfum di Algeria. Hasilnya membuktikan bahwa citra merek, kualitas, harga, perilaku masa lalu dan variabel perilaku memiliki dampak positif yang signifikan pada niat pembelian parfum. Lien et al., (2015) berhasil membuktikan efek langsung citra merek dan harga terhadap niat pembelian jasa hotel di Taiwan. Calvo \& Porral, (2015) membuktikan bahwa citra label pribadi dan kualitas yang dirasakan pada niat pembelian sebagian dimediasi oleh loyalitas dan dimoderatori oleh identifikasi pabrik.

Hasil riset juga mengungkapkan bahwa citra toko dan reputasi perusahaan meningkatkan citra label pribadi dan kualitas yang dirasakan. Riset lainnya seperti Ryu et al,. (2008) juga menyimpulkan bahwa citra restoran memiliki efek positif pada nilai yang dirasakan konsumen dan keinginan untuk membeli. Citra merek yang bagus meningkatkan kepercayaan konsumen sehingga dapat mengurangi risiko pembelian (Chiang \& Jang, 2007). Pengaruh kualitas dan harga terhadap minat beli juga berhasil dibuktikan oleh Konuk, (2015) dan Beneke et al., (2013). Dapat dinyatakan bahwa baik citra merek, harga ataupun kualitas produk/jasa sudah banyak terbukti secara empiris sebagai predictor intensi pembelian, sehingga hipotesis yang diajukan adalah :

H4 : Citra merek berpengaruh langsung terhadap intensi pembelian

H5 : Persepsi kualitas berpengaruh langsung terhadap intensi pembelian

H6 : Persepsi harga berpengaruh langsung terhadap intensi pembelian

H7 : Hubungan citra merek terhadap intensi pembelian dimediasi oleh persepsi kualitas dan harga

Model penelitian terdiri dari anteseden intensi pembelian termasuk citra merek, persepsi kualitas dan harga, menyelidiki pengaruh citra merek, kualitas dan harga terhadap intensi pembelian, dan menguji pengaruh citra merek terhadap intensi pembelian dengan menempatkan kualitas dan harga sebagai mediator. Model yang diusulkan ditunjukkan pada Gambar. 1. 


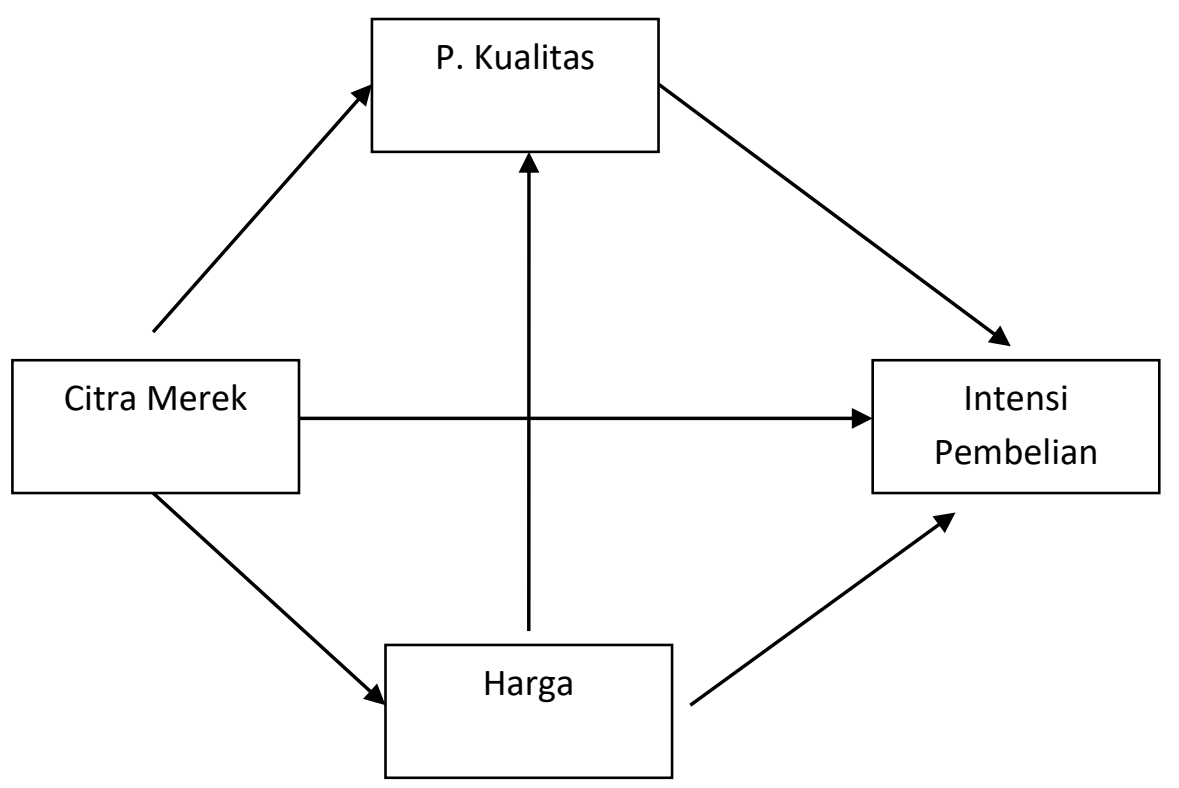

Gambar 1. Kerangka Konseptual

\section{Metode Penelitian}

\subsection{Prosedur Sampel}

Sampel penelitian adalah konsumen yang membeli produk parfum merek $\mathrm{X}$ di Kota Jakarta. Ukuran sampel didasarkan pada acuan dasar minimum sampel untuk PLSSEM yaitu 10 kali jumlah jalur pada inner model (Barclay et al., 1995 dalam Hair et al., 2012). Seperti terlihat pada Gambar 1, jumlah jalur antar variabel pada inner model adalah sebanyak 6 , sehingga ukuran minimum sampel adalah $6 \times 10=60$. Didasarkan pada pertimbangan ini, sebanyak 165 kuesioner disebar ke konsumen, dan yang kembali adalah sebanyak 117 (tingkat pengembalian 71\%). Ukuran sampel sebanyak 117 ini sudah memenuhi syarat minimum seperti yang dinyatakan oleh Hair et al., (2012). Pengambilan sampel dilakukan menggunakan metode convenience sampling.

Tabel 1. Deskripsi Responden $(n=117)$

\begin{tabular}{lll}
\hline & Frekuensi & \% \\
\hline Jenis Kelamin & & \\
Laki-Laki & 28 & 23.9 \\
Wanita & 89 & 76.1 \\
Usia & & \\
$18-20$ & 26 & 22.2 \\
$21-30$ & 38 & 32.5 \\
$31-40$ & 35 & 29.9 \\
$41-50$ & 8 & 6.8 \\
$51+$ & 10 & 8.5 \\
Status Pernikahan & & \\
Ya & 78 & 66.7 \\
Tidak & 22 & 18.8
\end{tabular}


Sebanyak $76.1 \%$ responden adalah wanita dan $23.9 \%$ laki-laki. Usia responden berkisar antara 21 - 30 tahun merupakan responden terbanyak (32.5\%), yang disusul responden berusia $31-40$ tahun (29.9\%). Usia 18 - 20 tahun menempati urutan ketiga dengan persentasi sebanyak $22.2 \%$, kemudian usia $41-50$ tahun sebanyak $6.8 \%$ dan di atas 51 tahun sebanyak 6.5\%. Status pernikahan responden adalah $66.7 \%$ berstatus menikah, $18.8 \%$ berstatus tidak menikah, dan $14.5 \%$ tidak bersedia memberikan jawaban.

\subsection{Pengukuran variabel}

Intensi pembelian pelanggan diukur pada 5 item yang diadaptasi dari Shukla (2010) dan Lien et al., (2015) meliputi : merek parfum bisa diandalkan, merek parfum ini menarik, merek parfum ini mudah diingat, merek parfum ini symbol status sosial, merek parfum ini memiliki reputasi yang bagus. Persepsi kualitas produk diukur dengan 5 item yang diadaptasi Ramaseshan dan Tsao (2007) meliputi fungsional (2 item), simbolik (2 item) dan pengalaman ( 1 item). Harga terdiri dari 5 item yang dimodifikasi dari Chiang dan Jang (2007) dan Dodds et al. (1991) meliputi: harga parfum ini terjangkau, harga parfum ini wajar, harga sesuai dengan kualitas, harga parfum ini bersaing dengan merek lain, harga sesuai dengan manfaat. Tiga Item citra merek diadaptasi dari Keller (2013) dan Lien et al., (2015) meliputi : setelah meninjau ulang produk ini, kemungkinan pemesanan parfum ini, jika saya akan membeli parfum, saya akan mempertimbangkan untuk membeli parfum ini, kemungkinan besar saya akan membeli produk ini. Total 18 item diukur dengan skala Likert lima poin mulai dari "sangat tidak setuju = 1" sampai dengan "sangat setuju $=5$ ".

\subsection{Teknik Analisis}

Teknik analisis yang digunakan adalah Partial Least Squares Structural Equation Modeling (PLS-SEM) dengan bantuan Program WarpPLS versi 5.0. Penggunaan teknik analisis ini didasarkan pada pertimbangan data yang berskala ordinal dan tidak berdistribusi normal sehingga covariance-based SEM (CB-SEM) tidak bisa dilakukan. PLS-SEM sendiri sudah menjadi metode alternatif dalam penelitian manajemen dan bisnis akhir-akhir ini dikarenakan tiga alasan yaitu data tidak normal, ukuran sampel yang kecil dan penggunaan indikator formatif. (Hair et al., 2014). Studi ini menggunakan acuan dari Henseler, et al. (2009), Hair et al., (2012, 2014) untuk mengestimasi dan melaporkan hasil PLS-SEM. Analisis terdiri dari dua tahap: penilaian model pengukuran (outer model), dan (2) penilaian model struktural (inner model).

\section{Hasil Dan Pembahasan}

\subsection{Evaluasi Outer Model}

Evaluasi model pengukuran berarti menguji kecocokan model pengukuran yaitu hubungan antara variable dengan item pertanyaan yang digunakan sebagai variabel manifest. Evaluasi ini terdiri dari convergent validity dan discriminant validity. Validitas konvergen sebagai sejauh mana item dalam konstruksi benar-benar mewakili konstruksi laten yang dimaksud (Hair et al., 2011). Validitas konvergen dinilai dengan menggunakan bobot faktor, average variance extracted (AVE) dan composite reliability. 
Reliabilitas indikator untuk SEM-PLS didasarkan pada nilai koefisien bobot faktor standar $\geq 0,70$, untuk penelitian eksploratif koefisien bobot faktor sebesar 0,40 sudah dapat diterima (Hulland, 1999). Composite reliability (CR) dan Cronbach's Alpha adalah ukuran reliabilitas dimana nilai minimal yang direkomendasikan adalah 0,70, Hair et al., (2011). Meskipun demikian dalam studi eksploratory, nilai CR 0,60 sampai 0,70 masih dapat dipertimbangkan untuk diterima, sedangkan nilai composite reliability (CR) kurang dari 0,60 menunjukan reliabilitas yang rendah. Ukuran convergent validity ketiga adalah nilai AVE atau average variance extracted. Nilai ini adalah menggambarkan seberapa besar kandungan variasi item pertanyaan yang ada dalam variable. Semakin tinggi nilai AVE menunjukan sifat convergent validity yang dapat diterima. Rule of thumb untuk nilai AVE menurut Hair et al., (2012) adalah diatas 0,50.

Seperti ditunjukkan pada Tabel 2, hasil reliabilitas indikator berkisar antara 0,71 sampai 0,97. Loading factor untuk semua item berada di atas nilai yang disarankan 0,50. Keandalan konsistensi internal dievaluasi dengan Composite reliability (CR). Nilai reliabilitas komposit berada pada kisaran 0,809-0,844 yang melampaui nilai minimum 0,70 (Hair et al., 2011) (lihat Tabel 2). Ini menunjukkan reliabilitas konsistensi internal yang sesuai dari ukuran. Selain itu, nilai AVE berada pada kisaran 0,522-0,618 yang melampaui nilai minimum 0,50 .

Pada tahap selanjutnya adalah pengujian validitas diskriminan. Validitas diskirminan dipenuhi jika masing-masing akar AVE lebih tinggi daripada korelasi antar variabel laten (Hair et al., 2011). Berdasarkan Tabel 3 dapat diketahui bahwa nilai akar AVE seluruhnya lebih tinggi dari korelasi antar variabel laten, sehingga dapat disimpulkan bahwa model sudah memenuhi validitas diskriminan.

Tabel 2. Evaluasi Validitas Konvergen

\begin{tabular}{lllll}
\hline & $\begin{array}{l}\text { Loading } \\
\text { Factor }\end{array}$ & CR & $\begin{array}{l}\text { Cronbach } \\
\text { Alpha }\end{array}$ & AVE \\
\hline Citra Merek (BRAND) & & & & \\
BI1 & 0.92 & & \\
BI2 & 0.94 & & \\
BI3 & 0.81 & 0.975 & 0.704 & 0.885 \\
BI4 & 0.97 & & \\
BI5 & 0.84 & & \\
Kualitas Produk (QUAL) & & & \\
PQ1 & 0.91 & & \\
PQ2 & 0.90 & & \\
PQ3 & 0.90 & 0.962 & 0.767 \\
PQ4 & 0.81 & & \\
PQ5 & 0.76 & & \\
Harga (PRICE) & & & \\
PR1 & & & \\
PR2 & 0.82 & & \\
PR3 & 0.81 & & \\
PR4 & 0.84 & & \\
PR5 & 0.72 & & \\
Intensi Pembelian (PURCHASE) & & & \\
\end{tabular}

Jurnal STEI Ekonomi, Vol. 27, No. 01, Juni 2018 


\begin{tabular}{|c|c|c|c|c|}
\hline PI1 & 0.80 & \multirow[b]{2}{*}{0.829} & \multirow[b]{2}{*}{0.689} & \multirow{3}{*}{0.618} \\
\hline PI2 & 0.87 & & & \\
\hline PI3 & 0.87 & & & \\
\hline \multicolumn{5}{|c|}{ Keterangan $: \mathrm{CR}=$ construct reliability, $\mathrm{AVE}=$ average variance extracted.} \\
\hline \multicolumn{5}{|c|}{ Tabel 3. Evaluasi Validitas Diskriminan } \\
\hline & BRAND & QUAL & PRICE & PURCHASE \\
\hline \multirow[t]{2}{*}{ Akar AVE } & 0.941 & 0.914 & 0.877 & 0.907 \\
\hline & BRAND & QUAL & PRICE & PURCHASE \\
\hline BRAND & 1.000 & 0.183 & 0.299 & 0.230 \\
\hline QUAL & 0.183 & 1.000 & 0.496 & 0.281 \\
\hline PRICE & 0.299 & 0.496 & 1.000 & 0.309 \\
\hline PURCHASE & 0.230 & 0.281 & 0.309 & 1.000 \\
\hline
\end{tabular}

Sumber : data diolah

\subsection{Evaluasi Inner Model}

Kriteria utama untuk penilaian model struktural adalah koefisien determinasi $\left(\mathrm{R}^{2}\right)$, yang mewakili jumlah varians yang dijelaskan dari masing-masing variabel laten endogen, atau kemampuan variabel laten eksogen menjelaskan variasi variabel laten endogen. Varians yang dijelaskan $\mathrm{R}^{2}$ nilai variabel laten endogen dievaluasi dengan nilai 0,75 (dinyatakan substansial), nilai 0,50 (dinyatakan sedang) dan 0,25 (dinyatakan lemah) (Hair et al, 2011). Untuk menguji relevansi prediktif model penelitian, statistik digunakan perhitungan $\mathrm{Q}^{2}$ Stone-Geisser. Nilai $\mathrm{Q}^{2}$ dikelompokkan menjadi tiga tingkat relevansi prediktif yaitu : 0,02 (kecil); 0,15 (sedang); dan 0,35 (besar).

Model struktural melaporkan nilai $\mathrm{R}^{2} 0.29$ pada QUAL, 0.21 pada PRICE dan 0.17 pada PURCHASE. Hasil ini menunjukkan bahwa angka $\mathrm{R}^{2}$ seluruhnya pada kategori lemah $\left(\mathrm{R}^{2}<0.25\right)$. Sedangkan nilai $\mathrm{Q}^{2}$ dapat dihitung sebagai berikut (Suryani dan Hendryadi, 2015) :

$$
\begin{aligned}
& \mathrm{Q}^{2}=1-\left(1-\mathrm{R}^{2}{ }_{1}\right)\left(1-\mathrm{R}^{2}{ }_{2}\right)\left(1-\mathrm{R}^{2}{ }_{3}\right), \text { sehingga } \\
& \mathrm{Q}^{2}=1-(1-0.29)(1-0.21)(0.17) \\
& \mathrm{Q}^{2}=0.54
\end{aligned}
$$

Hasil ini mengindikasikan bahwa seluruh model struktural memiliki relevansi prediktif dalam kategori besar $\left(\mathrm{Q}^{2}>0.35\right)$. Selanjutnya, hasil pengujian hipotesis ditampilkan sebagai berikut : 
Tabel 4. Hasil Pengujian Hipotesis

\begin{tabular}{|c|c|c|c|c|}
\hline & Jalur & Simbol & $\begin{array}{l}\text { Koefisien } \\
\text { Jalur } \\
\end{array}$ & Keterangan \\
\hline \multicolumn{5}{|c|}{ Hubungan Langsung } \\
\hline \multirow[b]{2}{*}{1} & & P1 & & Signifikan \\
\hline & BRAND $\rightarrow$ QUAL & & $0.200^{* *}$ & \\
\hline 2 & PRICE $\rightarrow$ QUAL & & $0.440^{* *}$ & \\
\hline 3 & BRAND $\rightarrow$ PRICE & $\mathrm{P} 3$ & $0.460^{* *}$ & Signifikan \\
\hline 4 & BRAND $\rightarrow$ PURCHASE & $\mathrm{P} 4$ & $0.170^{*}$ & Signifikan \\
\hline 5 & QUAL $\rightarrow$ PURCHASE & P5 & $0.180^{*}$ & Signifikan \\
\hline \multirow[t]{2}{*}{6} & PRICE $\rightarrow$ PURCHASE & P6 & $0.200^{* *}$ & Signifikan \\
\hline & Hubungan Tidak Langsung & & & \\
\hline $7 \mathrm{a}$ & BRAND --> QUAL --> PURCHASE & & 0.036 & Tidak signifikan \\
\hline \multirow[t]{2}{*}{$7 \mathrm{~b}$} & BRAND --> PRICE --> PURCHASE & & $0.092^{*}$ & Signifikan \\
\hline & \multicolumn{4}{|c|}{ Keterangan : *signifikan di level $0.05, * *$ signifikan di level 0.01} \\
\hline \multicolumn{5}{|c|}{$\begin{array}{l}\text { Evaluasi model struktural digunakan untuk menguji hubungan yang } \\
\text { dihipotesiskan. Sejalan dengan nilai dan signifikansi koefisien jalur (ditunjukkan pada } \\
\text { Tabel 4), citra merek terbukti memiliki dampak signifikan dan positif terhadap kualitas } \\
\left(\rho_{1}=0.200 \text {, sig, } 0.01\right) \text {, kemudian harga juga terbukti berpengaruh positif dan signifikan } \\
\text { terhadap perspesi kualitas }\left(\rho_{2}=0.440 \text {, sig, } 0.01\right) \text {. Dengan demikian, H1 dan H2 berhasil } \\
\text { dibuktikan. }\end{array}$} \\
\hline \multicolumn{5}{|c|}{$\begin{array}{l}\text { Citra merek pada hipotesis ke-3 juga berhasil dibuktikan memiliki pengaruh } \\
\text { positif dan signifikan terhadap harga }\left(\rho_{3}=0.460 \text {, sig, } 0.01\right) \text { dan intensi pembelian }\left(\rho_{4}=\right. \\
0.170 \text {, sig, } 0.03) \text {. Persepsi kualitas dan harga terbukti secara signifikan mempengaruhi } \\
\left.\text { intensi pembelian ( } \rho_{5}=0.180 \text {, sig, } 0.02\right) \text { dan }\left(\rho_{6}=0.200 \text {, sig, } 0.01\right) \text {. Dapat dinyatakan } \\
\text { bahwa H3, H4, H5 dan H6 berhasil didukung berdasarkan data empiris. }\end{array}$} \\
\hline \multicolumn{5}{|c|}{$\begin{array}{l}\text { Pengaruh tidak langsung citra merek terhadap intensi pembelian melalui kualitas } \\
\text { adalah sebesar } 0.036 \text { (tidak signifikan), dan melalui harga sebesar } 0.096 \text { dan signifikan di } \\
\text { level } 5 \% \text {. Oleh karenanya, model hubungan tidak langsung yang berhasil dibuktikan } \\
\text { hanyalah pada citra merek melalui harga, sedangkan kualitas tidak terbukti sebagai } \\
\text { pemediator. }\end{array}$} \\
\hline
\end{tabular}




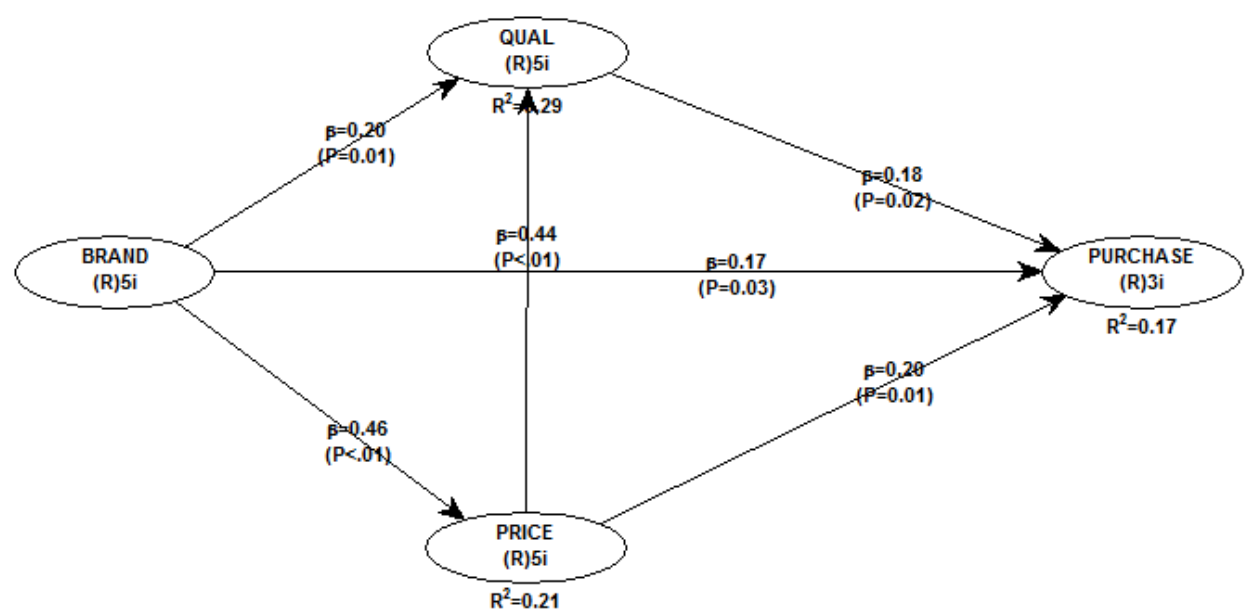

Gambar 2. Model Estimasi PLS-SEM

Penelitian ini memberikan kontribusi pada literatur dalam memeriksa dampak citra merek, kualitas, harga dan intensi atau niat beli konsumen, dan menguji peran mediasi kualitas dan harga pada hubungan citra merek ke intensi pembelian. Hasilnya mengkonfirmasi seluruh jalur langsung (direct effect) yang menunjukkan citra merek berpengaruh positif terhadap persepsi kualitas, harga, dan intensi pembelian. Kualitas ditemukan memiliki efek positif terhadap intensi pembelian, namun tidak terbukti sebagai mediator hubungan citra merek ke intensi pembelian. Sedangkan harga, selain terbukti berpengaruh positif terhadap persepsi kualitas dan intensi pembelian, juga terbukti berperan sebagai mediator hubungan citra merek ke intensi pembelian.

Citra merek terbukti secara signifikan mempengaruhi persepsi kualitas. Dengan demikian, citra merek yang kuat dapat membentuk persepsi kualitas dan relevan dengan penelitian Chiang dan Jang (2007) dan Khan et al., (2014) yang juga menyimpulkan bahwa citra merek memiliki efek positif pada persepsi kualitas. Dengan demikian, semakin kuat citra merek yang dirasakan konsumen, maka akan semakin kuat pula persepsi mereka terhadap kualitas produk. Citra merek berpengaruh positif terhadap harga yang menunjukkan merek disenangi dan bereputasi meningkatkan tingkat harga dan meningkatkan nilai produk / layanan. Temuan ini konsisten dengan Ryu et al., (2008) dan Lien et a., (2015). Citra merek juga merupakan penentu intensi pembelian, meskipun memiliki pengaruh paling lemah dibandingkan kualitas dan harga. Temuan ini konsisten dengan temuan Chihab, \& Abderrezzak, (2016); Lien et al., (2015); Calvo \& Porral, (2015).

Harga merupakan faktor kunci atau penggerak utama perspesi kualitas dan harga. Harga secara positif mempengaruhi persepsi kualitas, dan konsisten dengan penelitian Ye et al., (2014) dan Herbst et al., (2013). Artinya, konsumen merasa bahwa harga merupakan salah satu determinan kualitas, atau dengan kata lain, harga yang tinggi mencerminkan kualitas produk yang baik. Harga merupakan faktor kunci yang secara positif mempengaruhi niat beli yang menunjukkan bahwa harga yang dapat diterima dan sesuai akan meningkatkan niat pembelian konsumen. Hasilnya konsisten dengan penelitian Chiang dan Jang (2007). Persepsi kualitas merupakan faktor yang mempengaruhi intensi pembelian. Artinya, semakin baik kualitas yang dirasakan oleh konsumen maka akan mendorong niat pembelian di masa depan. Hasil penelitian ini konsisten dengan Konuk, (2015) dan Beneke et al., (2013). 
Penelitian ini hanya berhasil membuktikan bahwa harga dapat ditempatkan sebagai mediator hubungan antara citra merek dan intensi pembelian, sedangkan persepsi kualitas tidak terbukti sebagai mediator. Dengan demikian penelitian ini lebih mendukung konsep teoritis yang menempatkan persepsi kualitas sebagai variabel eksogen, dan bukan sebagai mediator sehingga berbeda dengan penelitian Chiang dan Jang (2007) dan Khan et al., (2014).

\section{SIMPULAN, KETERBATASAN DAN SARAN \\ 5.1. Simpulan}

Studi ini memberikan kesimpulan: pertama, citra merek dan harga merupakan dua faktor penting pembentuk persepsi kualitas produk. Untuk meningkatkan persepsi kualitas, pelaku bisnis kosmetik dapat meningkatkan citra merek melalui berbagai media promosi dan menetapkan harga bersaing (tidak terlalu tinggi, atau terlalu rendah dibandingkan dengan pesaing). Kedua, citra merek yang baik dapat mempengaruhi penerimaan harga oleh konsumen. Dengan kata lain, konsumen yang menyenangi sebuah merek tidak akan terlalu mempermasalahkan harga. Implikasi temuan ini adalah pemasar perlu mempertimbangkan penetapan harga yang dapat diterima oleh konsumen melalui survey harga terlebih dahulu untuk memastikan harga premium yang masih dalam taraf penerimaan konsumen. Ketiga, citra merek, persepsi kualitas, dan harga merupakan tiga komponen penting dalam menentukan intensi pembelian konsumen. Dengan demikian ketiganya dapat dijadikan strategi utama untuk menarik minat pembeli di masa depan.

Kesimpulan ke-empat, harga positif mempengaruhi niat beli dan memiliki efek mediasi pada citra merek dan intensi pembelitan. Implikasi temuan ini adalah para pemasar disarankan dapat mempertahankan harga sesuai dengan klasifikasi dan berhatihati untuk mencegah harga melebihi kisaran harga konsumen yang dapat diterima. Kelima, meskipun persepsi kualitas memiliki efek langsung terhadap intensi pembelian, namun perannya sebagai mediator hubungan citra merek dengan intensi pembelian tidak signifikan. Hal ini menunjukkan bahwa persepsi kualitas lebih tepat dijadikan sebagai predictor langsung ke intensi pembelian, dibandingkan ditempatkan sebagai mediator. Peran mediasi ini hanya berimplikasi pada kerangka teoritis sehingga model yang diajukan tidak mendukung persepsi harga sebagai mediator, melainkan faktor yang secara langsung mempengaruhi intensi pembelian.

\subsection{Keterbatasan dan Saran}

Penelitian ini memiliki dua keterbatasan. Pertama, hanya berfokus pada intensi pembelian produk parfum merek X di Jakarta. Oleh karena itu, generalisasi hasil pada model penelitian mungkin tidak berlaku untuk produk atau wilayah lain. Kedua, responden penelitian ini mayoritas diwakili oleh wanita, yang kemungkinan memiliki persepsi harga dan kualitas berbeda dengan laki-laki. Karakteristik sosio-demografis seperti pendapatan dan pekerjaan tidak secara spesifik diuji dalam penelitian ini. Berdasarkan keterbatasan tersebut, maka penelitian selanjutnya disarankan untuk melakukan kajian lintas wilayah, melakukan kajian pada beberapa merek produk sehingga memperoleh hasil yang lebih komprehensif. Penelitian mendatang juga perlu mempertimbangkan karakteristik responden seperti jenis kelamin dan tingkat pendapatan untuk mengontrol efek harga dan citra merek pada perilaku pembelian konsumen. 


\section{DAFTAR PUSTAKA}

Aaker, D.A. 1991, Managing Brand Equity: Capitalizing on the Value of a Brand Name, The Free Press, New York, NY.

Aaker, D. 1996, Building Strong Brands, The Free Press, New York, NY.

Aaker, D. A. 1996. Measuring brand equity across products and markets. California Management Review, 38, 102-120

Aaker, J. L. 1997, Dimensions of brand personality. Journal of Marketing Research, 34, $347-356$

Aghekyan-Simonian, M., Forsythe, S., Kwon, W. S., \& Chattaraman, V. 2012. The role of product brand image and online store image on perceived risks and online purchase intentions for apparel. Journal of Retailing and Consumer Services, 19(3), 325-331.

Andrews, M., Luo, X., Fang, Z., \& Aspara, J. 2014. Cause marketing effectiveness and the moderating role of price discounts. Journal of Marketing, 78(6), 120-142.

Aydin, S., \& Özer, G. 2005. The analysis of antecedents of customer loyalty in the Turkish mobile telecommunication market. European Journal of Marketing, 39(7/8), 910-925.

Beneke, J., Flynn, R., Greig, T., \& Mukaiwa, M. 2013. The influence of perceived product quality, relative price and risk on customer value and willingness to buy: a study of private label merchandise. Journal of Product \& Brand Management, 22(3), 218-228.

Bian, X., \& Moutinho, L. 2011. The role of brand image, product involvement, and knowledge in explaining consumer purchase behaviour of counterfeits: Direct and indirect effects. European Journal of Marketing, 45(1/2), 191-216.

Chiang, C. F., \& Jang, S. S. 2007. The effects of perceived price and brand image on value and purchase intention: Leisure travelers' attitudes toward online hotel booking. Journal of Hospitality \& Leisure Marketing, 15(3), 49-69.

Chua, B. L., Lee, S., Goh, B., \& Han, H. 2015. Impacts of cruise service quality and price on vacationers' cruise experience: Moderating role of price sensitivity. International Journal of Hospitality Management, 44, 131-145.

Calvo Porral, C., \& Lang, M. F. 2015. Private labels: The role of manufacturer identification, brand loyalty and image on purchase intention. British Food Journal, 117(2), 506-522.

Chihab, Zaidi Oussama, and Benhabib Abderrezzak. "Factors affecting Consumer Purchase Intention of Luxury Perfumes in Algeria: A case study of Consumers in the Twin Cities of Tlemcen and Sidi Bel Abbes." Journal of Research in Marketing 6.3 (2016): 461-467. 
Dodds, W. B., Monroe, K. B., \& Grewal, D. 1991. Effects of price, brand, and store information on buyers' product evaluations. Journal of Marketing Research, 28(3), 307-319.

Han, H., \& Hyun, S. S. 2015. Customer retention in the medical tourism industry: Impact of quality, satisfaction, trust, and price reasonableness. Tourism Management, 46, 20-29.

Hair, J.F., Sarstedt, M., Hopkins, L., \& G. Kuppelwieser, V. 2014. Partial least squares structural equation modeling (PLS-SEM) An emerging tool in business research. European Business Review, 26(2), 106-121.

Hair, J.F., Ringle C.M., and Sarstedt.M. 2011. PLS-SEM: Indeed a Silver Bullet. Journal of Marketing Theory and Practice, 19. 2, 139-151

Hair, J. F., Sarstedt, M., Ringle, C. M., \& Mena, J. A. 2012. An assessment of the use of partial least squares structural equation modeling in marketing research. Journal of the academy of marketing science, 40(3), 414-433.

Henseler, J., Ringle, C. M., \& Sinkovics, R. R. 2009. The use of partial least squares path modeling in international marketing. In New challenges to international marketing (pp. 277-319). Emerald Group Publishing Limited.

Herbst, K. C., Leary, M. R., \& McColskey-Leary, C. P. 2013. Social-evaluative influences moderate the relationship between price and perceived quality. Social Influence, 8(1), 54-69.

Hulland, J. S. 1999. Use of partial least squares (PLS) in strategic management research:A review of four recent studies. Strategic Management Journal, 20(4), 195-204

Hwang, Y., Ko, E., \& Megehee, C. M. 2014. When higher prices increase sales: How chronic and manipulated desires for conspicuousness and rarity moderate price's impact on choice of luxury brands. Journal of Business Research, 67(9), 19121920.

Khan, N., Rahmani, S. H. R., Hoe, H. Y., \& Chen, T. B. 2014. Causal relationships among dimensions of consumer-based brand equity and purchase intention: Fashion industry. International Journal of Business and Management, 10(1), 172.

Kim, H.W., Xu, Y., \& Gupta, S. 2012.Which is more important in Internet shopping, perceived price or trust? Electronic Commerce Research and Applications, 11(3), 241-252.

Konuk, F. A. 2015. The effects of price consciousness and sale proneness on purchase intention towards expiration date-based priced perishable foods. British Food Journal, 117(2), 793-804.

Kotler, P., \& Armstrong, G. 2008. Prinsip-prinsip Pemasaran, Jilid 1. Jakarta : Erlangga 
Keller, K.L. (1993), "Conceptualizing, measuring, and managing customer-based brand equity", Journal of Marketing, Vol. 57 No. 1, pp. 1-22.

Keller, K.L. 2012. Strategic Brand Management: Building, Measuring, and Managing Brand Equity, 4th Edition. Pearson.

Lien, C. H., Wen, M. J., Huang, L. C., \& Wu, K. L. 2015. Online hotel booking: The effects of brand image, price, trust and value on purchase intentions. Asia Pacific Management Review, 20(4), 210-218.

Ramaseshan, B., \& Tsao, H. Y. 2007. Moderating effects of the brand concept on the relationship between brand personality and perceived quality. Journal of Brand Management, 14(6), 458-466.

Ranjbarian, B., Sanayei, A., Kaboli, M. R., \& Hadadian, A. 2012. An analysis of brand image, perceived quality, customer satisfaction and re-purchase intention in Iranian department stores. International Journal of Business and Management, 7(6), 40.

Ryu, K., Han, H., \& Kim, T. H. 2008. The relationships among overall quick-casual restaurant image, perceived value, customer satisfaction, and behavioral intentions. International Journal of Hospitality Management, 27(3), 459-469.

Saleem, H., \& Raja, N. S. 2014. "The impact of service quality on customer satisfaction, customer loyalty and brand image: Evidence from hotel industry of Pakistan". Middle-East Journal of Scientific Research, 19(5), 706-711.

Suryani, S, \& Hendryadi, H. 2015, A developing model of relationship among service quality, consumer satisfaction, loyalty and word of mouth in Islamic banking. AlIqtishad: Journal of Islamic Economics, 7(1), 45-58.

Shukla, A., Sharma, N. K., \& Swami, S. 2010, Website characteristics, user characteristics and purchase intention: mediating role of website satisfaction". International Journal of Internet Marketing and Advertising, 6(2), 142-167.

Swait, J. and Erdem, T. 2007, Brand effects on choice and choice set formation under uncertainty”, Marketing Science, Vol. 26 No. 5, pp. 679-697

Webster, F.E. and Keller, K.L. 2004, A roadmap for branding in industrial markets, Brand Management, Vol. 11 No. 5, pp. 388-402

Whan Park, C., MacInnis, D. J., Priester, J., Eisingerich, A. B., \& Iacobucci, D. 2010. Brand attachment and brand attitude strength: Conceptual and empirical differentiation of two critical brand equity drivers. Journal of marketing, 74(6), 117.

Wu, P. C., Yeh, G. Y. Y., \& Hsiao, C. R. 2011. The effect of store image and service quality on brand image and purchase intention for private label brands. Australasian Marketing Journal (AMJ), 19(1), 30-39. 
Ye, Q., Li, H., Wang, Z., \& Law, R. 2014. The influence of hotel price on perceived service quality and value in e-tourism: an empirical investigation based on online traveler reviews. Journal of Hospitality \& Tourism Research, 38(1), 23-39.

Yoo, B., and Donthu, N. 2001. Developing and validating a multidimensional consumerbased brand equity scale. Journal of business research, 52(1), 1-14

Zeithaml, V. A. 1988. Consumer perceptions of price, quality, and value: A means-end model and synthesis of evidence. Journal of Marketing, 52, 2-22. 